\title{
PENINGKATAN KOMPETENSI GURU MELALUI PEMBELAJARAN BERBASIS WHITEBOARD ANIMATION SEDERHANA BERBANTUAN EXPLEE
}

\author{
Fauzi Mulyatna'), Abdul Karim¹), Indah Mayang Purnama1) \\ 1)Program Studi Pendidikan Matematika, Fakultas Matematika dan IPA, Universitas Indraprasta PGRI, Jakarta Timur, \\ DKI Jakarta, Indonesia \\ Corresponding author : Fauzi Mulyatna \\ E-mail : fauzi.mulyatna@unindra.ac.id
}

Diterima 05 Februari 2021, Disetujui 26 Februari 2021

\begin{abstract}
ABSTRAK
Corona Virus Disease (Covid-19) membawa dampak yang sangat besar bagi sektor pendidikan. Salah satunya adalah pergeseran pembelajaran yang tadinya terdapat tatap muka menjadi Pembelajaran Jarak Jauh (PJJ). Hal ini membuat guru sebagai pendidik dituntut kreatif dalam menyampaikan materi melalui media pembelajaran online. Seorang guru dapat dikatan professional jika mampu beradaptasi dengan perkembangan ilmu pengetahuan serta mampu menerapkan model, metode, media, maupun pendekatan pembelajaran berdasarkan kebutuhan peserta didik. Sebagai upaya untuk meningkatkan profesionalisme guru, maka perlu dilakukan upaya berkesinambungan seperti kegiatan pelatihan maupun pembimbingan bagi guru. Tujuan dari kegiatan pengabdian kepada masyarakat ini untuk meningkatkan profesionalitas guru melalui kegiatan Pelatihan Peningkatan Kompetensi Guru Melalui Pembelajaran Berbasis Whiteboard Animation Sederhana Berbantuan Aplikasi Explee. Bentuk kegiatan yang telah dilakukan yaitu 1) memperkenalkan konsep whiteboard animation; 2) memperkenalkan tahapan pembuatan media ajar berbasis animasi dari mulai pra produksi, produksi, hingga pasca produksi; 3) mengenalkan bahan ajar digital berbasis whiteboard animation tematik sesuai dengan mata pelajaran yang diampu.
\end{abstract}

Kata kunci: pelatihan; whiteboard animation; aplikasi Explee.

\begin{abstract}
Corona Virus Disease (Covid-19) has a huge impact on the education sector. One of them is the shift of learning that was once face-to-face to Distance Learning (PJJ). This makes teachers as educators are required to be creative in delivering materials through online learning media. A teacher can be a professional if he is able to adapt to the development of science and is able to apply models, methods, media, and learning approaches based on the needs of learners. As an effort to increase the professionalism of teachers, it is necessary to make continuous efforts such as training and mentoring activities for teachers. The purpose of this community service activity is to improve teacher professionalism through Teacher Competency Improvement Training through Simple Whiteboard Animation-Based Learning Assisted by Explee Application. The form of activities that have been done is 1) introducing the concept of whiteboard animation; 2) introduce the stages of making animationbased teaching media from pre-production, production, to post-production; 3 ) introduce digital teaching materials based on thematic whiteboard animation in accordance with the subjects that are mastered.
\end{abstract}

Keywords: training; whiteboard animation; explee application.

\section{PENDAHULUAN}

Saat ini hampir seluruh negara di belahan dunia sedang dilanda penyakit global (pandemik) covid-19, yang berdampak besar pada berbagai sektor kehidupan salah satunya sektor pendidikan (World Health Organization (WHO), 2020). Salah satu dampak yang paling terlihat jelas adalah pergeseran pembelajaran yang tadinya terdapat tatap muka menjadi Pembelajaran Jarak Jauh (PJJ). Sesuai dengan edaran Menteri Pendidikan dan Kebudayaan
Republik Indonesia terkait Surat Edaran Nomor 4 Tahun 2020 tentang Pelaksanaan Kebijakan Pendidikan dalam Masa Darurat Penyebaran Corona Virus Disease (Covid-19), setiap pembelajaran jarak jauh dilakukan melalui perangkat Personal Computer (PC) atau laptop yang terhubung dengan koneksi jaringan internet, serta dapat memanfaatkan aplikasi media sosial sebagai alternatif penyampaian materi pembelajaran. 
Hal ini mungkin dianggap berat oleh pendidik dan peserta didik, terlebih pendidik harus dituntut kreatif dalam menyampaikan materi melalui media pembelajaran online. Pendidik, baik guru, harus memastikan bahwa kegiatan pembelajaran tetap berjalan dan materi yang disampaikan tetap diterima dengan baik oleh peserta didik, meskipun peserta didik belajar dari rumah. Seorang pendidik dapat dikatakan sebagai agen pembelajaran (learning agent) karena memiliki peran antara lain sebagai fasilitator, motivator, pemacu, perekayasa pembelajaran, dan pemberi inspirasi belajar bagi peserta didik sehingga tujuan pendidikan nasional dapat terwujud (Hikmawati et. al., 2018).

Pada semua tingkatan, tujuan pendidikan adalah dapat melibatkan seluruh peserta didik dalam pembelajaran bermakna, yang dapat terjadi selama proses pemeblajaran. Belajar adalah proses mengalami, sehingga peserta didik dapat membangun pengetahuan lebih lanjut dan mengembangkan keterampilan yang sudah dimilikinya. Apalagi, pada era teknologi ini, sudah terjadi pergeseran paradigma yang mengharuskan seorang pendidik untuk terus berupaya mengembangkan metode, strategi, dan media pembelajaran yang efektif dan tepat sasaran, sehingga pembelajaran yang efektif dan bermakna dapat terwujud (Nurrahmah et. al., 2019).

Pendidik selalu dituntut agar mampu mengembangkan dan menggunakan alat-alat pembelajaran sesuai dengan tuntutan perkembangan zaman. Pendidik dituntut untuk dapat mengembangkan keterampilan dalam membuat media pembelajaran yang dapat digunakannya dalam proses pembelajaran. Akibatnya, mau tidak mau, pendidik dituntut harus membuat atau mendesain pembelajaran dengan memanfaatkan media sebagai bentuk inovasi pembelajaran (Nugraha \& Sudiyono, 2018).

Kenyataan yang terjadi di lapangan adalah masih banyak pendidik yang menerapkan metode konvensional pada proses pembelajaran. pembelajaran matematika di kelas masih menggunakan metode konvensional. Penerapan metode konvensional, menyebabkan tidak terlibat secara aktif selama pembelajaran karena pendidik berperan sebagai pusat pembelajaran (Seruni et. al., 2019).

Hal ini tentu bukanlah sesuatu yang mudah dilakukan karena tidak semua pihak sepenuhnya siap dengan kondisi yang terjadi saat ini, baik pada masing-masing instansi, pendidik, maupun peserta didik. Pada masa pandemik, dapat dikatakan bahwa keadaan yang terjadi saat ini merupakan peluang dalam pendidikan, karena kita dipaksa untuk mampu memanfaatkan teknologi. Harapannya, setelah pandemi ini berakhir, pendidik maupun peserta didik terbiasa untuk memanfaatkan teknologi pada proses pembelajaran.

Ada banyak software yang dapat dimanfaatkan oleh pendidik untuk membuat dan mengembangkan media pembelajaran yang inovatif dan mudah untuk digunakan. Salah satunya adalah menggunakan aplikasi Explee yang dapat di-download secara gratis (tidak berbayar). Aplikasi Explee dapat membantu dalam pembuatan materi pelajaran sesuai dengan keinginan pendidik, tanpa harus memiliki penguasaan lebih di bidang teknologi. Pendidik hanya perlu mengembangkan cerita dan alur pada video pembelajaran secara kreatif agar materi pelajaran terlihat menarik dan mudah dipahami peserta didik.

Berdasarkan pemaparan di atas, maka dilakukanlah kegiatan pengabdian kepada masyarakat dengn tema Peningkatan Kompetensi Guru Melalui Pembelajaran Berbasis Whiteboard Animation Sederhana Berbantuan Explee.

\section{METODE}

Waktu pelaksanaan kegiatan selama bulan Oktober hingga Januari tahun 2021, kegiatan pelatihan dilaksanakan selama 4 bulan. Kegiatan pelatihan ini akan dilaksanakan di SMA Negeri 1 Sukra, yang beralamat di Jalan Raya Sukra-Ujung Gebang Km. 0.5 Desa Sukra Kecamatan Sukra Kabupaten Indramayu, Jawa Barat. Pada kegiatan pengabdian kepada masyarakat ini, metode yang digunakan adalah pelatihan, pembimbingan serta melakukan pendampingan yang diintegrasikan melalui kegiatan peningkatan kompetensi guru melalui pembelajaran berbasis whiteboard animation sederhana berbantuan Explee. Metode yang digunakan untuk mencapai tujuan yang telah dirumuskan di atas. Materi yang diberikan saat pelatihan memuat pengenalan, perancangan dan penerapan. Pelaksanaan kegiatan ini dilakukan dalam tiga tahap, yaitu tahap persiapan, pelaksanaan, dan evaluasi. 1) Tahap persiapan. Pada tahap persiapan, tim melakukan diskusi dengan pihak terkait untuk mengetahui kondisi target kegiatan dan menyusun rancangan kegiatan yang akan dilakukan, serta bagaimana mekanisme penyampaian materi kegiatan secara online agar efektif dan tepat sasaran. Media online yang tim gunakan melalui aplikasi zoom meeting.; 2) Tahap pelaksanaan. Tahap pelaksanaan peserta pelatihan diberikan materi mengenai perancangan dengan storyboard, paparan whiteboard animation berbantuan 
Explee, latihan atau praktik di mana peserta berlatih membuat media interaktif tematik menggunakan whiteboard animation sesuai dengan mata pelajaran yang diampu.; 3) Tahap monitoring dan evaluasi. Pada tahap ini, peserta mengumpulkan tugas berupa media pembelajaran animasi yang sudah dibuat oleh peserta. Tahap terakhir adalah evaluasi, di mana peserta memberikan tanggapan atas kegiatan workshop melalui kuesioner yang akan dibagikan oleh tim melalui google form.

\section{HASIL DAN PEMBAHASAN}

Sesuai dengan skema yang sudah direncanakan oleh tim abdimas, pelaksanaan kegiatan ini dilakukan dalam tiga tahap, yaitu tahap persiapan, pelaksanaan, dan evaluasi. Realisasi pelaksanaan sesuai dengan perencanaan tim pelaksana. Pada tahap evaluasi dan monitong, terkendala oleh situasi karena guru tidak lagi melakukan pembelajaran di kelas, namun melakukan Pembelajaran Jarak Jauh (daring).

Pada tahap persiapan, tim pelaksana berkomunikasi dengan Wakil Kepala Kurikulum SMA bernama Siha Abdurohim, M.Pd melalui Whatsapp. Dari hasil diskusi tersebut, didapatkan bahwa permasalahan yang dihadapi guru adalah: 1) tidak semua guru memiliki pemahaman dan pengetahuan yang baik mengenai media pembelajaran yang inovatif dan interaktif.; 2) Masalah lain yang dialami adalah sudah ada banyak aplikasi media pembelajaran yang dapat dimanfaatkan oleh pendidik sebagai bahan ajar, namun tidak setiap aplikasi tersebut sesuai dengan selera dan gaya mengajar tiap-tiap guru. Sehingga, akan lebih baik jika seorang guru memiliki kemampuan untuk menggunakan dan memanfaatkan aplikasi media pembelajaran interaktif tersebut, sesuai dengan gaya mengajar dan seleranya.

Berdasarkan masalah tersebut, tim pengabdian dan pihak SMA Negeri 1 Sukra sepakat mengadakan kegiatan pengabdian masyarakat untuk meningkatkan kompetensi guru melalui pelatihan peningkatan kompetensi guru melalui pembelajaran berbasis whiteboard animation sederhana berbantuan Explee yang akan dilakukan melalui Daring menggunakan aplikasi zoom meeting. Tujuan kegiatan ini adalah untuk memperkenalkan konsep whiteboard animation berbantuan Explee; memperkenalkan tahapan pembuatan media ajar berbasis animasi dari mulai pra produksi, produksi, hingga pasca produksi; mengenalkan bahan ajar digital berbasis whiteboard animation berbantuan Explee tematik sesuai dengan mata pelajaran yang diampu.
Adapun pelatihan peningkatan
kompetensi guru melalui pembelajaran berbasis whiteboard animation sederhana berbantuan Explee, yang meliputi: 1) memperkenalkan konsep whiteboard animation; 2) memperkenalkan tahapan pembuatan media ajar berbasis animasi dari mulai pra-produksi, produksi, hingga pasca produksi; 3) mengenalkan bahan ajar digital berbasis whiteboard animation tematik sesuai dengan mata pelajaran yang diampu. Hari Kamis dan Jum'at, tanggal 5-6 November 2020.

Pada hari Kamis, 5 November 2020, pada pukul 7.30 tim menyebarkan link zoom ke grup peserta, agar peserta dapat masuk ke ruang zoom meeting. Pukul 08.00 kegiatan dimulai dengan pemberian sambutan yang diawali oleh perakilan tim pengabdian yang disampaikan oleh Bapak Fauzi Mulyatna, M.Pd. selanjutnya, sambutan oleh Wakil Kepala Kurikulum SMA Bapak Siha Abdurohim, M.Pd sekaligus membuka kegiatan pelatihan dan diakhiri dengan doa oleh Bapak Iman Tantoni S.Pd. Pada pukul 09.00 kegiatan dilanjutkan dengan penyampaian materi pertama "perancangan dengan storyboard dan storyline" yang disampaikan oleh Bapak Fauzi Mulyatna, M.Pd. Pada materi perancangan dengan storyboard dan storyline, disampaikan bahwa storyboard dan storyline merupakan sebuah langkah awal bagaimana kita menyusun sebuah narasi atau cerita. Cara membuat cerita kita mentukan tema, gaya bercerita dan mentukan plot atau cerita (pembukaan, materi inti dan penutup). $\mathrm{Di}$ dalam konsep pengembangan pembelajaran storyboard dan storyline merupakan tahap disain yang bagaimana guru menyusun sekenario yang akan digunakan di dalam whiteboard animation. Materi pertama disampaikan selama 45 menit hingga pukul 09.50. Pada materi pertama ini guru diberikan template storyboard dan storyline agar dapat dipahami oleh masing masing peserta abdimas.

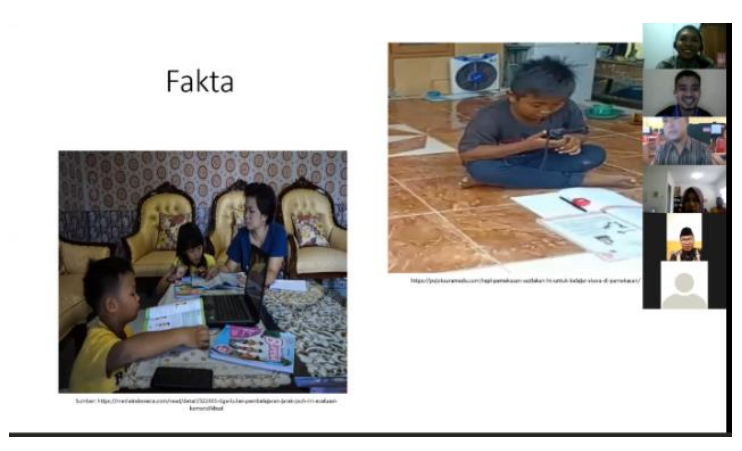

Gambar 1. Penyampaian Materi 1 
Materi selanjutnya, mengenai "whiteboard animation" disampaikan oleh Yogi Wiratomo, M.Pd hingga pukul 13.00. Materi ini, terkait langkah-langkah menyusun sekenario, hal terpenting yang harus diperhatikan pada pembuatan narasi atau cerita. Dalam penyusunan skenario whiteboard animation diusahan jangan dibuat terlalu panjang, karna umumnya peserta didik akan tertarik dengan video pembelajaran dengan durasi 3-5 menit. Kalau durasinya menjadi panjang kemungkinan peserta didik akan menjadi jenuh. Pada pukul 13.05 kegitan ditutup dan akan dilanjutkan pada hari Jumat dangan memberikan tugas kepada masing-masing guru untuk menyelesaikan storyboard dan storyline.

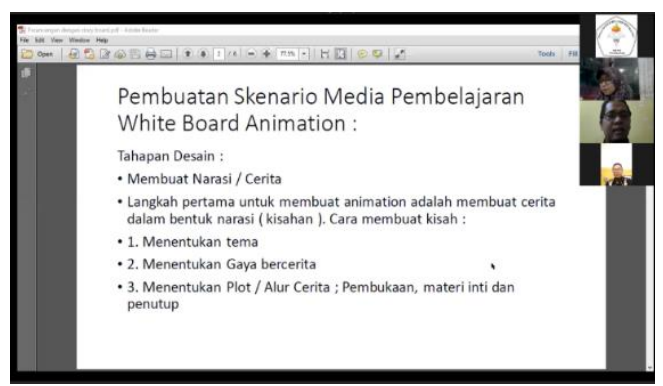

Gambar 2. Penyampaian Materi 2

Pada hari Jumat, 6 November 2020, pada pukul 7.30 tim menyebarkan link zoom ke grup peserta, agar peserta dapat masuk ke ruang zoom meeting. Pada pukul 08.05 kegiatan dibuka oleh W.K. Kurikulum SMA Bapak Siha Abdurohim, M.Pd. selanjutnya, materi ketiga "aplikasi Explee" ketiga disampaikan oleh Yogi Wiratomo, M.Pd. Pada materi ini, diberikan tutorial whiteboard animation menggunakan Explee. 1) Masuk kedalam aplikasi Explee; 2) membuat video pembelajaran dengan menggunakan aplikasi Explee; 3) merubah format project yang dibuat ke dalam format video seperti .mp4. Pada penjelasan tutorial ini guru mengikuti arahan yang diberikan oleh lbu Indah sehingga terjadi interaksi di dalam ruang zoom meeting. Kegiatan berakhir pada pukul 13.00 yang ditutup oleh Bapak Siha Abdurohim, M.Pd dan dipimpin doa oleh Bapak Iman Tantoni S.Pd.

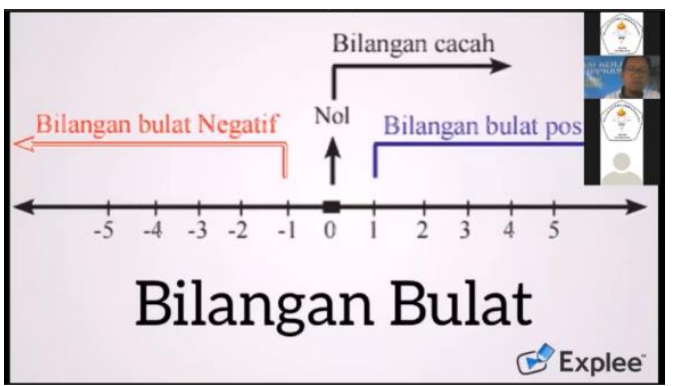

Gambar 3. Penyampaian Materi 3
Pada akhir pertemuan ini guru diberikan tugas untuk mengumpulkan hasil vidio yang dibuat melalui link google form. Waktu pengumpulan untuk tugas adalah selama satu minggu dan tim abdimas membentuk kelompok diskusi di dalam Whatsapp guna memudahkan para peserta untuk bertanya apabila terdapat kendala atau kesulitan dalam pembuatan vidio.

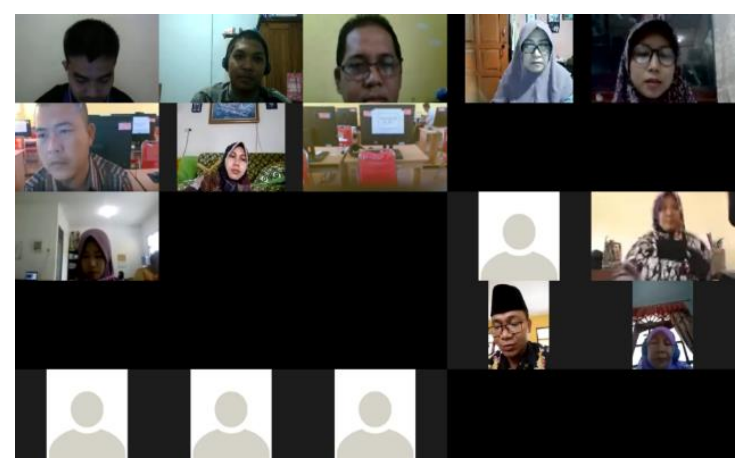

Gambar 4. Peserta Kegiatan Pelatihan

Tahap selanjutnya, adalah kegiatan monitoring dan pendampingan melalui Whatsapp di mana guru dapat menanyakan pada tim jika mengalami kendala atau kesulitan ketika pembuatan vidio pembelajaran berbasis whiteboard animation.

Salah satu upaya yang dilakukan untuk meningkatkan kinerja maupun keprofesionalisme guru melalui berbagai pelatihan dan pembinaan, seperti yang dilakukan oleh tim pengabdian masyarakat yaitu PKM Peningkatan Kompetensi Guru Melalui Pembelajaran Berbasis Whiteboard Animation Sederhana Berbantuan Explee di SMA Negeri 1 Sukra Indramayu. Adapun pelatihan yang diberikan meliputi materi: perancangan dengan storyboard dan storyline; whiteboard animation; Explee.

Media whiteboard animation yang berisi vidio interaktif yang dirancang oleh guru untuk memudahkan peserta didik dalam memahami materi yang akan diajarkan (Wijayanti et. al., 2018). Whiteboard animation sendiri merupakan media komunikasi yang dibuat oleh si pengirim kepada penerima melalui simbolsimbol yang ada didalam whiteboard animation. Di dalam whiteboard animation disedikan fiturfitur yang memudahkan pengguna dalam mengembangkan vidio yang akan dibuat. Media ini akan menarik perhatian peserta didik tergatung dari kreatifitas guru dalam merancang alur cerita yang dibuat.

Terdapat empat kelebihan dalam pengunaan vidio animasi yaitu: 1) Objek pembelajaran dapat disajikan secara real sehingga peserta didik dapat merasakan pengalaman belajar yang berbeda; 2) 
penggunaan media vidio dapat memotivasi peserta didik karena membangun daya tarik dan semangat belajar; 3) dengan menggunakan media vidio dapat meningkatkan kemampuan psikomotorik peserta didik; dan 4) media vidio dapat mengurangi kejenuhan dalam proses pembelajaran (Sanaky, 2011). Hal ini tidak terlepas dari kreatifitas guru dalam merancang storyboard dan storyline yang dibuat.

Salah satu contoh aplikasi whiteboard animation adalah Explee. Aplikasi Explee merupakan aplikasi yang hampir sama seperti vidioscribe yang merupakan sebuah aplikasi pembuat konten vidio materi pembelajaran yang dapat dibuat sesuai keinginan pemakainya tanpa harus memiliki keterampilan yang lebih dibidang teknologi. Pemanfaatan Explee ini hanya memerlukan ide dan kreatifitas dalam menyusun storyboard dan storyline dalam penyusunan vidionya. Oleh sebab itu pemahaman dalam membuat alur cerita menjadi kunci keberhasilan dalam pembuatan vidio.

\section{SIMPULAN DAN SARAN}

Kegiatan pelatihan ini dapat dikatakan terlaksana dengan baik walaupun kurang maksimal karena kegiatan monitoring yang sedikit terkendala sehingga tidak dapat menghasilkan luaran yang diinginkan sesuai dengan rencana yang sudah disusun oleh tim kegiatan. Namun, secara umum kegiatan Peningkatan Kompetensi Guru Melalui Pembelajaran Berbasis Whiteboard Animation Sederhana Berbantuan Explee di SMA Negeri 1 Sukra Indramayu sudah berlangsung dengan baik.

\section{DAFTAR RUJUKAN}

Hikmawati, H., Rokhmat, J., \& Sutrio, S. (2018). Penyuluhan Pembuatan Media Tiga Dimensi dan Penerapannya Melalui Model Siklus Belajar 5E Pada Guru-Guru di MGMP Fisika Se-Lombok Barat. Jurnal Pendidikan Dan Pengabdian Masyarakat, 1(1), $\quad$ 1-8. http://jurnalfkip.unram.ac.id/index.php/JP PM/article/view/479/0

Nugraha, D. A., \& Sudiyono, S. (2018). Pelatihan dan Pendampingan Pembuatan Media Pembelajaran Interaktif Menggunakan Autoplay Media Studio Bagi Guru-Guru Sdn Merjosari 1. Jurnal Terapan Abdimas, 3(2), 182. https://doi.org/10.25273/jta.v3i2.2811

Nurrahmah, A., Mulyatna, F., \& Rusmana, I. M. (2019). PkM Model Pembelajaran di Pondok Pesantren An-Nahl Darunnajah 5 Cikeusik. SELAPARANG Jurnal
Pengabdian Masyarakat Berkemajuan, 3(1), 53. https://doi.org/10.31764/jpmb.v3i1.976

Sanaky, H. A. (2011). Media Pembelajaran: Buku Pegangan Wajib Guru Dan Dosen. Kaukaba.

Seruni, S., Mulyatna, F., \& Nurrahmah, A. (2019). Pkm Inovasi Pembelajaran Matematika Sd/Mi Melalui Permainan Ular Tangga. SELAPARANG Jurnal Pengabdian Masyarakat Berkemajuan, 3(1), 75. https://doi.org/10.31764/jpmb.v3i1.1128

Wijayanti, R., Hasan, B., \& Loganathan, R. K. (2018). Media comic math berbasis whiteboard annimation dalam pelajaran matematika. Jurnal Riset Pendidikan Matematika, 5(1), 53. https://doi.org/10.21831/jrpm.v5i1.19207

World Health Organization (WHO). (2020). Novel Coronavirus (2019-nCoV) SITUATION REPORT - 1. https://www.who.int/docs/defaultsource/coronaviruse/situationreports/20200121-sitrep-1-2019ncov.pdf?sfvrsn=20a99c10_4 